\title{
Numerical investigation on the effect of a modified corrugated double tube heat exchanger on heat transfer enhancement and exergy losses
}

\author{
S.M. Pesteei*, Nemat Mashoofi, Saman Pourahmad, Ashkan Roshan \\ Department of Mechanical Engineering, Faculty of Engineering, Urmia University, Urmia, Iran \\ Email: sm.pesteei@urmia.ac.ir
}

\begin{abstract}
In the present study, heat transfer and exergy losses in a double-tube heat exchanger with corrugated inner tubes were investigated. The inner tube of the heat exchanger with a diameter of $27 \mathrm{~mm}$ was made of copper and outer tube with a diameter of $54 \mathrm{~mm}$ was assumed insolated. First, semi-elliptical corrugations were created on the outer surface of inner tube of double tube heat exchanger. In addition, to delay the separation of flow, modified corrugations, consisting of a quarter of elliptic and an inclined line, were used, too. Results show that using corrugated tubes with semi-elliptical corrugations over inner tube of double-tube heat exchanger has significant effects on heat transfer and exergy losses. In addition, modified corrugations delay the separation of flow compared to semi-elliptical corrugations which increase heat transfer further. Also, results indicate that increase in heat transfer increases exergy losses.
\end{abstract}

Keywords: Double-Tube Heat Exchanger, Exergy Losses, Heat Transfer, Modified Corrugated Tube.

\section{INTRODUCTION}

Enhancing the heat transfer in heat exchangers increases the overall efficiency of the system. Various passive and active methods have been used to increase heat transfer in heat exchangers in recent years. Using modified tubes such as corrugated tubes, helical tubes and finned tubes as inner tube of double-tube heat exchangers are some examples of this method. Achieving higher heat transfer rate by increasing heat transfer area and increasing flow mixing in the boundary layer is the main goal for these methods.

Safikhani [1,2] numerically studied heat transfer and pressure drop in flat tubes with different geometries using Al2O3/water nanofluid as working fluids. Results showed that by flattening the tube, heat transfer increases which accompanies significant increases in pressure drop. After choosing the efficient flat tubes, single and dual co-twisted tapes and counter twisted tapes were inserted in the flat tube. Results indicated that in presence of turbulators heat transfer and pressure drop increased. In the case with two counter twisted tapes in the flat tube, heat transfer was increased by $30 \%$ but friction factor was raised by $220 \%$. Pethkool et al. [3] investigated the effect of using corrugated helical tubes as inner tube of a double-tube heat exchanger on some parameters including heat transfer. Effect of corrugation depth on heat transfer was examined in their study. Results indicated that modified tubes increase the heat transfer significantly compared to plain tubes. Han et al. [4] investigated the effect of implementing corrugated tubes as inner tube of double-tube heat exchangers. Corrugations on inner tubes were formed of semi-circles with various radiuses.
Effect of corrugation radius and space between corrugations were studied. Z. Zhang et al. [5] used finned tubes equipped with twisted baffles on the outer surface as inner tube of a double-tube heat exchanger.

It was observed that $\mathrm{Nu}$ number and pressure drop were increased up to 3.33 and 1.11 times the plain heat exchanger. W. Zhang et al. [6] numerically and experimentally investigated on performance of single-row finned tubes in air cooled power plant. They studied 4 schemes and compared them and found that pressure drop in flattened finned tube reduced $5.9 \%$ while heat transfer coefficient was reduced by $2.8 \%$. In 2017, Asif et al. [7] numerically studied on the heat transfer in corrugated plate heat exchanger. They found that Nussulet number was increases by increasing of chevron angle. G. Lorenzini and S. Moretti [8] investigated on heat transfer and related characteristics which are created in electronic circuits. By removing this problem, faster and better circuits can be made which makes this study very valuable.

Because of small dimensions in circuits, their real challenge was to find the optimal design in small sized heat exchangers. Ibrahim [9] used flat tubes as inner tube of a double-tube heat exchanger. In addition, effect of using twisted tapes in inner tube of the heat exchanger on heat transfer and pressure drop was investigated. Experiments were carried out for turbulators with different pitch ratios and results were compared. Results indicated that by increasing the Reynolds number and decreasing pitch ratio of turbulator, $\mathrm{Nu}$ number increases. Heat transfer in the flat tube was significantly increased compared to the plain tube. Pourahmad and Pesteei [10] experimentally investigated the 
effect of using wavy strip turbulators in the inner tube of a double-tube heat exchanger on heat transfer enhancement. A new correlation was developed for effectiveness and NTU based on experimental data. Mashoofi et al. [11] used helical wire turbulators in a coil double-tube heat exchanger. According to their results, using helical wire turbulators affects heat transfer significantly.

Also, using passive methods affects exergy losses in heat exchangers where some great studies have been done. Akpinar [12] used swirl generators in a double-tube heat exchanger. By creating swirl flow in the double-tube heat exchanger, heat transfer and exergy losses were increased significantly. Air was used as the hot fluid in inner tube and water as cold fluid in the annulus. Results indicated that using these turbulators increased the Nu number up to 1.3 times as compared to the plain tube heat exchanger. In addition, exergy losses were greatly increased. In 2016, Kaliakatsos et al. [13] investigate heat transfer and pressure drop in pipe equipped with twisted tape insert. They found that this type of insert have major effect of on heat transfer because of swirl flow witch made by insert. Brahim et al. [14] investigated performance of heat transfer in roll heat tube witch used in refrigerator system in their study, the effects wick characterizations and heat pipe diameter and length were studies.

Considering the mentioned studies, it results that various passive methods have been used to increase heat transfer in the heat exchanger so far. In addition, the effect of corrugated tubes with semi-circle corrugations as inner tube of the double-tube heat exchanger on heat transfer and exergy losses is vastly studied. In the present study, the effect of corrugated tubes with semi-elliptical corrugations on heat transfer and exergy losses on a double-tube heat exchanger is investigated for the first time. Also to delay the separation of flow, modified corrugations were used.

\section{NUMERICAL MODELING}

\subsection{Physical model}
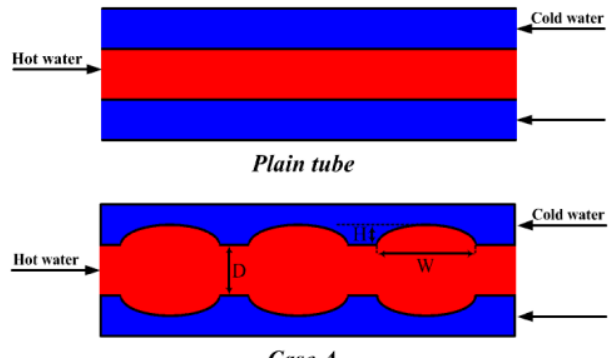

Case A


Figure 1. Schematic of the physical models and flow arrangements.
In the present study, corrugated tubes were used as inner tube of a double-tube heat exchanger to increase heat transfer. The inner tube of the heat exchanger with a diameter of 27 $\mathrm{mm}$ was made of copper and outer tube with a diameter of 54 $\mathrm{mm}$ was assumed to be insulated.

Firstly, semi-elliptical corrugations (case A) were used on the inner tube of the double-tube heat exchanger. Then, modified corrugations consisting of a quarter of an elliptic and an inclined line were used in order to delay separation of flow compared to case A. Modified corrugations with two arrangements of co-flow-direction (case B) and counter-flowdirection (case $\mathrm{C}$ ) were investigated. Three different heights of corrugations $(\mathrm{H})$ including 2.5, 3.75 and $6 \mathrm{~mm}$ were used in designing the semi-elliptical while in all cases; the axial diameter of the ellipse (W) was kept at a constant value of 15 $\mathrm{mm}$.

Fig 1. shows schematic of the physical models and flow arrangements.

\subsection{Governing equations and boundary conditions}

In the present study, finite element method was used to discretizing of equations. For the derivation of the continuity, momentum, and energy equations the water was considered a Newtonian and an incompressible fluid with constant thermophysical properties to derive continuity, momentum and energy equations. These equations are as follows [15-18]: Continuity equation:

$$
\frac{\partial}{\partial \mathrm{x}_{\mathrm{i}}}\left(\mathrm{pu}_{\mathrm{i}}\right)=0
$$

Momentum equation:

$\left.\frac{\partial\left(\mathrm{pu}_{\mathrm{i}} \mathrm{u}_{\mathrm{j}}\right)}{\partial \mathrm{x}_{\mathrm{j}}}=-\frac{\partial \mathrm{p}}{\partial \mathrm{x}_{\mathrm{i}}}+\frac{\partial}{\partial \mathrm{x}_{\mathrm{j}}} \mid \mu\left(\frac{\partial \mathrm{u}_{\mathrm{i}}}{\partial \mathrm{x}_{\mathrm{j}}}+\frac{\partial \mathrm{u}_{\mathrm{j}}}{\partial \mathrm{x}_{\mathrm{i}}}\right)\right]-\frac{2}{3} \mu \frac{\partial \mathrm{u}_{\mathrm{k}}}{\partial \mathrm{x}_{\mathrm{k}}} \delta_{\mathrm{ij}}$

Energy equation:

$$
\frac{\partial}{\partial \mathrm{x}_{\mathrm{i}}}\left(\mathrm{\rho u}_{\mathrm{j}} \mathrm{C}_{\mathrm{p}} \mathrm{T}-\mathrm{k} \frac{\partial \mathrm{T}}{\partial \mathrm{x}_{\mathrm{j}}}\right)=\mathrm{u}_{\mathrm{j}} \frac{\partial \mathrm{p}}{\partial \mathrm{x}_{\mathrm{j}}}+\left[\mu\left(\frac{\partial \mathrm{u}_{\mathrm{i}}}{\partial \mathrm{x}_{\mathrm{j}}}+\frac{\partial \mathrm{u}_{\mathrm{j}}}{\partial \mathrm{x}_{\mathrm{j}}}\right)\right]-\frac{2}{3} \mu \frac{\partial \mathrm{u}_{\mathrm{k}}}{\partial \mathrm{x}_{\mathrm{k}}} \delta_{\mathrm{ij}}
$$

For turbulence kinetic and momentum equations, upper hand second order discretizing was used. To simulate the turbulent flow, k-e method RNG model was used.

Turbulent kinetic energy equation [13-16]:

$$
\frac{\partial}{\partial \mathrm{x}_{\mathrm{i}}}\left(\mathrm{pku}_{\mathrm{i}}\right)=\frac{\partial}{\partial \mathrm{x}_{\mathrm{j}}}\left[\left(\mu+\frac{\mu_{\mathrm{t}}}{\sigma_{\mathrm{k}}}\right) \frac{\partial \mathrm{k}}{\partial \mathrm{x}_{\mathrm{j}}}\right\rfloor+\mathrm{G}_{\mathrm{k}}-\rho \varepsilon
$$

Turbulent kinetic energy dissipation:

$$
\frac{\partial}{\partial \mathrm{x}_{\mathrm{i}}}\left(\rho \varepsilon \mathrm{u}_{\mathrm{i}}\right)=\frac{\partial}{\partial \mathrm{x}_{\mathrm{j}}}\left\lfloor\left(\mu+\frac{\mu_{\mathrm{t}}}{\sigma_{z}}\right) \frac{\partial \varepsilon}{\partial \mathrm{x}_{\mathrm{j}}}\right\rfloor+\mathrm{C}_{1 z} \frac{\varepsilon}{\mathrm{k}} \mathrm{G}_{\mathrm{k}}-\mathrm{C}_{2 \varepsilon} \rho \frac{\varepsilon^{2}}{\mathrm{k}}
$$

\subsection{Boundary conditions}

Velocity inlet is chosen for hot and cold water inlets as the inlet boundary condition. Also, pressure outlet is chosen for outlet boundary condition. It must be noted that outlet 
pressure is considered to be zero. Flow is in turbulence regime and heat exchanger uses a counter-flow system. The hot and cold water inlet temperatures were kept constant at $327 \mathrm{~K}$ and $303 \mathrm{~K}$, respectively. The inner tube is made of copper and the outer tube is insulated. No slip condition was considered for all the surfaces. Thermodynamical properties of fluid were based on hot and cold water inlet temperature and extracted from thermodynamical tables.

\section{DATA PROCESSING}

\subsection{Heat transfer rate equation}

Transferred heat from hot fluid and cold fluid can be calculated as follow:

$$
\begin{aligned}
& Q_{\mathrm{h}}=\dot{m}_{\mathrm{h}} c_{\mathrm{p}, \mathrm{w}}\left(T_{\mathrm{h}, \mathrm{i}}-T_{\mathrm{h}_{\ell} 0}\right) \\
& Q_{\mathrm{c}}=\tilde{m}_{\mathrm{c}} c_{\mathrm{p}, \mathrm{w}}\left(T_{\mathrm{c}_{i, 0}}-T_{\mathrm{c}, \mathrm{i}}\right)
\end{aligned}
$$

Average heat transfer is:

$$
Q_{\mathrm{nx}}=\frac{Q_{\mathrm{s}}+Q_{\mathrm{h}}}{2}
$$

\subsection{Exergy loss equation}

Exergy is the maximum theoretical work that can be obtained at the end of a reversible process. Temperature difference and pressure drop are two main reasons for exergy losses. Since most of the studies done on exergy losses of heat exchangers are because of temperature difference, only thermal irreversibility was investigated in the present study. Exergy loss for a double-tube heat exchanger with hot and cold water, as working fluid can be written as follow:

$\mathrm{E}=\mathrm{E}_{\mathrm{h}}+\mathrm{E}_{\mathrm{c}}$

Exergy losses for hot and cold water are [19]:

$\mathrm{E}_{\mathrm{h}}=\mathrm{T}_{\mathrm{e}}\left[\mathrm{m}_{\mathrm{h}}\left(\mathrm{s}_{\mathrm{h}_{\mathrm{j}} \mathrm{O}}-\mathrm{s}_{\mathrm{h}, \mathrm{i}} \mathrm{i}\right)\right]$

$\mathrm{E}_{\mathrm{c}}=\mathrm{T}_{\mathrm{e}}\left[\mathrm{m}_{\mathrm{c}}\left(\mathrm{s}_{\mathrm{c}, \rho}-\mathrm{s}_{\mathrm{c}, \mathrm{i}}\right)\right]$

By inserting substituting Eq. (10) and Eq. (11) into Eq. (9):

$$
\begin{aligned}
& \mathrm{E}=\mathrm{T} \text { ? } \mathrm{e} \text { ? }[\mathrm{m} \text { ? ? } \mathrm{h} \text { ? }(\mathrm{s} \text { ? } \mathrm{h}, \mathrm{o} \text { ? }-\mathrm{s} \text { ? } \mathrm{h}, \mathrm{i} \text { ? })+
\end{aligned}
$$

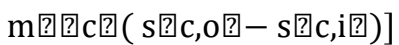

For Incompressible liquid, entropy changes can be calculated as:

$$
\begin{aligned}
& s_{h_{j} 0}-s_{h_{j} \mathrm{i}}=C_{p_{j} w} \ln \frac{T_{h_{j} 0}}{T_{h_{j}}} \\
& \mathrm{~s}_{\mathrm{c}, 0}-\mathrm{s}_{\mathrm{c}, \tilde{\mathrm{i}}}=\mathrm{C}_{\mathrm{p}, \mathrm{w}} \ln \frac{\mathrm{T}_{\mathrm{c}, \rho}}{\mathrm{T}_{\mathrm{c}, \mathrm{i}}}
\end{aligned}
$$

By inserting Eq. (13) and Eq. (14) into Eq. (12), following correlation, can be used to calculate heat exchanger exergy losses:

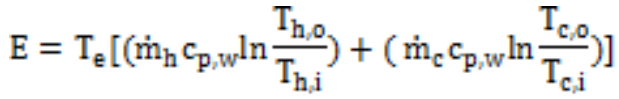

Noting that in all cases hot water flow rate was less than the cold water flow rate, maximum and minimum heat capacities can be calculated as follows:

$$
\begin{aligned}
& \mathrm{c}_{\max }=\dot{\mathrm{m}}_{\mathrm{c}} \mathrm{c}_{\mathrm{p}, w} \\
& \mathrm{c}_{\min }=\dot{\mathrm{m}}_{\mathrm{h}} \mathrm{c}_{\mathrm{p}, W},
\end{aligned}
$$

Hence, exergy losses can be rewritten as follow:

$$
\mathrm{E}=\mathrm{T}_{\mathrm{e}}\left[\left(\mathrm{C}_{\min } \ln \frac{\mathrm{T}_{\mathrm{h}_{0} \mathrm{o}}}{\mathrm{T}_{\mathrm{h}, \mathrm{i}}}\right)+\left(\mathrm{C}_{\max } \ln \frac{\mathrm{T}_{\mathrm{C}_{j} \mathrm{O}}}{\mathrm{T}_{\mathrm{c}, \mathrm{i}}}\right)\right]
$$

\section{RESULTS AND DISCUSSION}

\subsection{Validation and grid independence study}

To investigate the independency of model results from meshing, four different meshing elements numbers of $0.9,1.3$, 1.5 and 1.8 million were created and used. The results in 1.8 million elements have $3 \%$ error compared to 1.5 million elements. Therefore, to keep a balanced trade-off between convergence time and solution accuracy, the adopted grid number in the computational domain was about 1.5 million. Fig. 2 shows the meshing model used in present study.
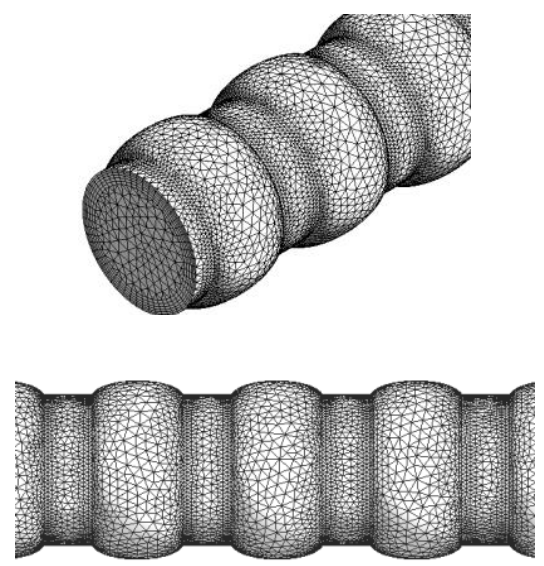

Figure 2. Meshing model used in present study

To have an assurance about accuracy in results, first an analysis of heat transfer in a plain double-tube heat exchanger was done and $\mathrm{Nu}$ numbers were compared with $\mathrm{Nu}$ numbers given by Dattus-Bolter correlation [20]. Fig.3 shows this comparison. The average difference between $\mathrm{Nu}$ numbers obtained by this study and the Dattus-Bolter correlation was $8 \%$ which shows a good accuracy of the present study.

$\mathrm{Nu}=0.023 \operatorname{Re}^{0.9} P r^{0.3}$ 


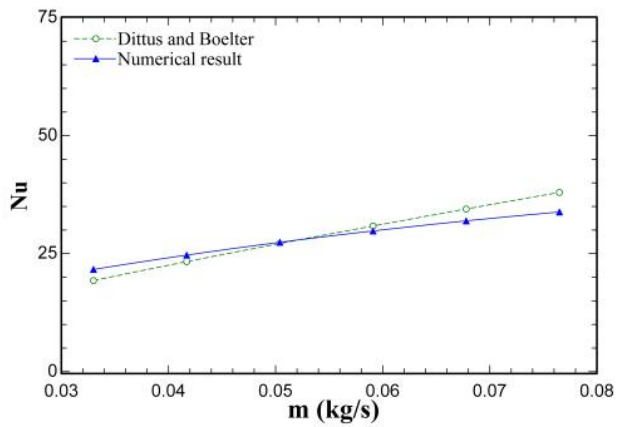

Figure 3. Validation for Nu number of a plain double-tube heat exchanger.

\subsection{Heat transfer analysis}

One of the advantages of corrugated tubes is the increase in heat transfer surface and turbulence in the flow. Therefore, using corrugated tubes increase heat transfer in a double-tube heat exchanger. The amount of improving heat transfer by using corrugated tubes depends on corrugation shapes. Changes in heat transfer with hot water flow rate for semielliptical corrugations (case A) are shown in Fig.4. As it is observed, increase in corrugation height (semi-elliptical vertical diameter) increases the heat transfer. Heat transfer in the double-tube heat exchanger with semi-elliptical corrugations was 1.15 to 2.22 times more than the plain double-tube heat exchanger.



Figure 4. Heat transfer changes with hot water flow rate for various heights, Case A

Streamline around the inner tube of the double-tube heat exchanger is shown in Fig.5. As it is observed, separation of flow happens in upper hand of corrugations. Separation of flow decreases the heat transfer.

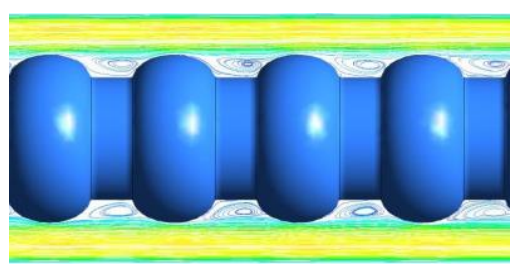

Figure 5. Streamline for cases A

Modified corrugations can be used to delay separation point of flow. They consist of a quarter of elliptic and an inclined line (cases B and C), and because of their enhanced aerodynamics, separation of flow from inner tube compared to a plain double-tube heat exchanger occurs with a delay.
Therefore, heat transfer in modified corrugations is enhanced compared to a plain corrugation (semi-elliptical). Changes in heat transfer rate with hot water flow rate for modified corrugations (case B and C) with different heights (semielliptical vertical diameter) are shown in Figs. 6 and 7. Three different heights of $2.5,3.75$ and $5 \mathrm{~mm}$ were used in designing mentioned corrugations. However, the width of corrugations (W) was a constant value of $15 \mathrm{~mm}$ (see Fig.1). As it can be observed, in cases $\mathrm{B}$ and $\mathrm{C}$, increasing the corrugation height increases the turbulence of flow and disturbing boundary layer which lead to an increase in heat transfer. According to obtained results, case $\mathrm{C}$ affects heat transfer greatly in double-tube heat exchanger compared to case $B$. so that in case $B$, heat transfer was 1.23 to 2.47 times more than a plain double-tube heat exchanger. Meanwhile for the same hot and cold water flow rates, for case $\mathrm{C}$, heat transfer increased up to 1.32 to 2.70 times the plain doubletube heat exchanger.

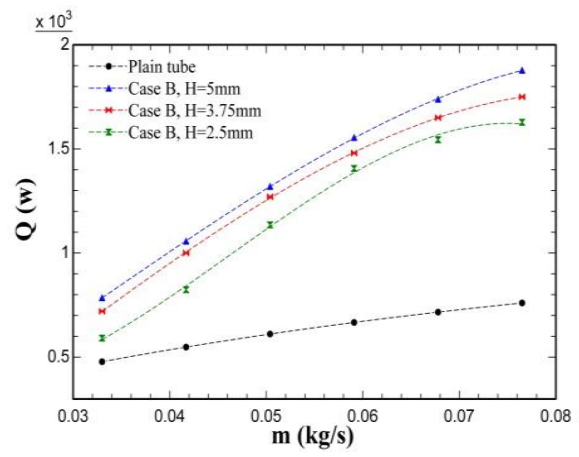

Figure 6. Changes in heat transfer with hot water flow rate for various heights, Case B.

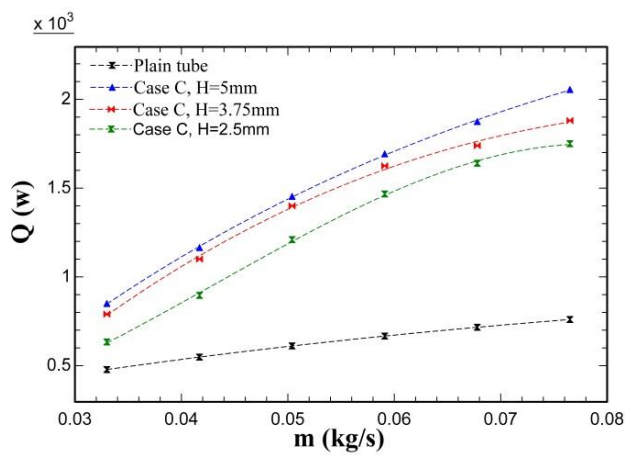

Figure 7. Changes in heat transfer with hot water flow rate for various heights, Case $\mathrm{C}$.

Streamline for cases B and $\mathrm{C}$ are shown in Figs. 8 and 9. In case B, working fluid separates from inner tube surface earlier (where the heat transfer between cold and hot water happens). Therefore, heat transfer in case B is less than that in case $\mathrm{C}$ which is because of difference aerodynamics of two flow directions.

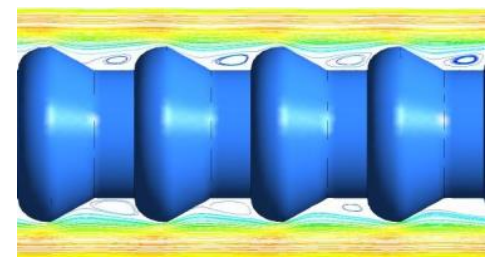

Figure 8. Streamline for cases B 




Figure 9. Streamlinefor cases C

\subsection{Exergy loss analysis}

Heat transfer due to the temperature difference, alike what happens in a double-tube heat exchanger, is an irreversible process. The more heat transfer, the more irreversibility will exist. Hence, exergy losses will increase. Changes in exergy losses with hot water flow rate for cases $\mathrm{B}$ and $\mathrm{C}$ for various corrugation heights are shown in Fig. 10 and 11. As it can be seen, increase in corrugation height increases the turbulence of flow, disturbing the boundary layer and heat transfer in the double-tube heat exchanger. Therefore, irreversibility and exergy losses increase, too. Also, with an increase in hot water flow rate, the turbulence of flow and heat transfer increase. Therefore, irreversibility and exergy losses increase, too. The highest irreversibility and exergy losses occurred in corrugated tubes with $5 \mathrm{~mm}$ height in case $\mathrm{C}$ in which exergy losses were 1.65 to 2.3 times over the exergy losses in the plain double-tube heat exchanger. Considering that heat transfer in case $\mathrm{C}$ is more enhanced compared to cases $\mathrm{A}$ and $\mathrm{B}$, exergy losses in this case, are more than cases A and B.



Figure 10. Changes in exergy losses for various heights, case B

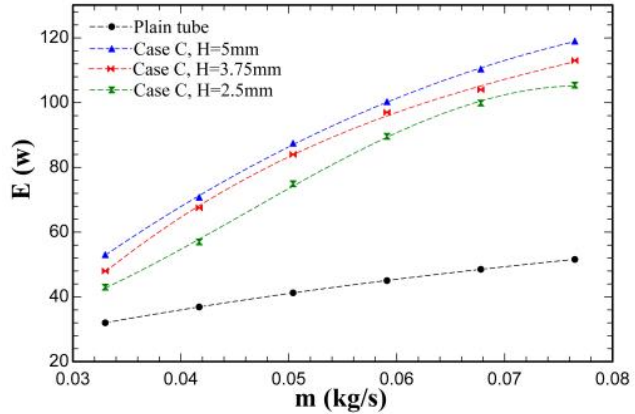

Figure 11. changes in heat transfer with hot water flow rate for various heights, Case B.

\section{CONCLUSION}

In the present study, corrugated tubes were used as inner tube of a double-tube heat exchanger and effect of using modified tubes on heat transfer and exergy losses was investigated. Firstly, semi-elliptical corrugations were created on the inner tube of a double-tube heat exchanger. Three different heights of $2.5,3.75$ and $5 \mathrm{~mm}$ were designed for corrugations. Then modified corrugations including a quarter of an elliptic and an inclined line were used and results were compared with plain a double-tube heat exchanger. Using corrugated tubes increase the heat transfer significantly. Results indicate that increasing the corrugation height increases heat transfer and exergy losses. In addition, for sake of better aerodynamics in case $C$, separation of flow delays in case $\mathrm{C}$ compared to cases $\mathrm{A}$ and $\mathrm{B}$. The highest heat transfer enhancement and increase in exergy losses occurred in case $\mathrm{C}$ with corrugation height of $5 \mathrm{~mm}$ which in action has a heat transfer of 1.32 to 2.70 times more than a plain double-tube heat exchanger.

\section{REFERENCES}

[1] Safikhani H., Abbassi A., Khalkhali A., Kalteh M. (2015). Multi-objective optimization of nanofluid flow in flat tubes using CFD, artificial neural networks and genetic algorithms, Advanced Powder Technology, Vol. 25, No. 5, pp. 1609-1617. DOI: 10.1016/j.apt.2014.05.014

[2] Safikhani H., Abbasi A. (2014). Numerical study of nanofluid flow in flat tubes fitted with multiple twisted tapes, Advanced Powder Technology, Vol. 26, No. 6, pp. 1608-1617. DOI: $10.1016 /$ j.apt.2015.09.002

[3] Pethkool S., Eiamsa-Ard S., Kwankaomeng S., Promvonge P. (2011). Turbulent heat transfer enhancement in a heat exchanger using helically corrugated tube, International Communications in Heat and Mass Transfer, Vol. 38, No. 3, pp. 340-347. DOI: 10.1016/j.icheatmasstransfer.2010.11.014

[4] Han H., Li B., Shao W. (2014). Multi-objective optimization of outward convex corrugated tubes using response surface methodology, Applied Thermal Engineering, Vol. 70, No. 1, pp. 250-262. DOI: 10.1016/j.applthermaleng.2014.05.016

[5] Zhang Z., Yu Z., Fang X. (2007). An experimental heat transfer study for helically flowing outside petalshaped finned tubes with different geometrical parameters, Applied Thermal Engineering, Vol. 27, No. 1 , pp. 268-272. DOI: 10.1016/j.applthermaleng.2006.07.008

[6] Zhang W., Liu H., Du X., Yang Y., Shi L. (2016). Numerical and experimental research on performance of single-row finned tubes in air cooled power plants, International Journal of Heat and Technology, Vol. 34, No. 1, pp. 137-142, 2016. DOI: 10.18280/ijht. 340120

[7] Asif M., Aftab H., Syed H.A., Ali M.A., Muizz P.M., Simulation of corrugated plate heat exchanger for heat and flow analysis, International Journal of Heat and Technology, Vol. 35, No. 1, pp. 205-210, 2017. DOI: 10.18280/ijht.350127

[8] Lorenzini G., Moretti S. (2009). Thermofluid dynamic performances numerical-constructal analysis of heat exchangers with standard and optimized profiles, 
International Journal of Heat and Technology, Vol. 27, No. 1, pp. 145-149.

[9] Ibrahim E. (2011). Augmentation of laminar flow and heat transfer in flat tubes by means of helical screwtape inserts, Energy Conversion and Management, Vol. 52, No. 1, pp. 250-257. DOI: 10.1016/j.enconman.2010.06.065.

[10] Pourahmad S., Pesteei S.M. (2016). EffectivenessNTU analyses in a double tube heat exchanger equipped with wavy strip considering various angles, Energy Conversion and Management, Vol. 123, pp. 462-469. DOI: 10.1016/j.enconman.2016.06.063

[11] Mashoofi N., Pesteei S.M., Moosavi A., Dizaji H.S. (2017). Fabrication method and thermal-frictional behavior of a tube-in-tube helically coiled heat exchanger which contains turbulator, Applied Thermal Engineering, Vol. 111, pp. 1008-1015. DOI: 10.1016/j.applthermaleng.2016.09.163

[12] Akpinar E.K., Bicer Y. (2005). Investigation of heat transfer and exergy loss in a concentric double pipe exchanger equipped with swirl generators, International Journal of Thermal Sciences, Vol. 44, No. 6, pp. 598-607. DOI: 10.1016/j.ijthermalsci.2004.11.001

[13] Kaliakatsos D., Cucumo M., Ferraro V., Mele M., vA., Accorinti F. (2016). CFD analysis of a pipe equipped with twisted tape, International Journal of Heat and Technology, Vol. 34, No. 2, pp. 172-180. DOI: 10.18280/ijht.340203

[14] Brahim T., Jemni A. (2012). A two dimensional steady state roll heat pipe analyses for heat exchanger applications, International Journal of Heat and Technology, Vol. 30, No. 2, pp. 115-120. DOI: 10.18280/ijht.300216

[15] Yang L., Han H., Li Y., Li X. (2016). A numerical study of the flow and heat transfer characteristics of outward convex corrugated tubes with twisted-tape insert, Journal of Heat Transfer, Vol. 138, No. 2, pp. 024501. DOI: $10.1115 / 1.4031171$

[16] Mohammed H., Hasan H.A., Wahid M. (2013). Heat transfer enhancement of nanofluids in a double pipe heat exchanger with louvered strip inserts, International Communications in Heat and Mass Transfer, Vol. 40, pp. 36-46. DOI: $\underline{10.1016 / j . i c h e a t m a s s t r a n s f e r .2012 .10 .023}$

[17] Eiamsa-ard P., Piriyarungroj N., Thianpong C., Eiamsa-ard S. (2014). A case study on thermal performance assessment of a heat exchanger tube equipped with regularly-spaced twisted tapes as swirl generators, Case Studies in Thermal Engineering, Vol. 3, pp. 86-102. DOI: 10.1016/j.csite.2014.04.002

[18] Ghadirijafarbeigloo S., Zamzamian A., Yaghoubi M. (2004). 3-D numerical simulation of heat transfer and turbulent flow in a receiver tube of solar parabolic trough concentrator with louvered twisted-tape inserts, Energy Procedia, Vol. 49, pp. 373-380. DOI: 10.1016/j.egypro.2014.03.040

[19] Akpinar E.K. (2006). Evaluation of heat transfer and exergy loss in a concentric double pipe exchanger equipped with helical wires, Energy Conversion and Management, Vol. 47, No. 18, pp. 3473-3486. DOI: 10.1016/j.enconman.2005.12.014

[20] Incropera F.P., Dewitt D. (2010). Fundamentals of Heat and Mass Transfer, John Wiley \& Sons.

\section{NOMENCLATURE}

A

$C_{p}$

$C_{\min }$

$\mathrm{C}_{\max }$

$\mathrm{H}$

W

m

Q

E

$\mathrm{T}$

s

\section{Subscripts}

ave average

c cold

h hot

in inlet

w water

e surface area of the test tube, $\mathrm{m} 2$

specific heat at constant pressure, J.kg-1.K-1

minimum heat capacity, W.K-1

maximum heat capacity, W.K-1

heights of corrugations, $\mathrm{mm}$

width of corrugations, $\mathrm{mm}$

mass flow rate, kg.s-1

heat transfer rate, $\mathrm{W}$

Exergy loss, W

water temperature, $\mathrm{K}$

specific entropy, j.kg-1.K-1

environment condition 